\title{
Arginine prevents thermal aggregation of hen egg white proteins
}

Taehun Honga ${ }^{\mathrm{a}}$, Kazuki Iwashita ${ }^{\mathrm{a}}$, Akihiro Handa ${ }^{\mathrm{b}}$, Kentaro Shirakia,*

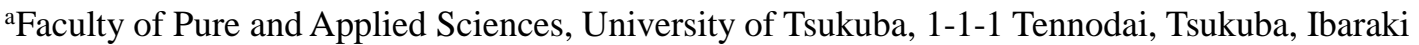
305-8573, Japan

${ }^{b}$ R\&D Division, Kewpie Corporation, 2-5-7 Sengawa, Chofu, Tokyo 182-0002, Japan

*Corresponding author. Tel.: +81 29 8535306; fax: +81 298535215 .

E-mail address: shiraki@bk.tsukuba.ac.jp. 


\section{Abstract}

The control of aggregation and solubilization of hen egg white protein (HEWP) is an important issue for industrial applications of one of the most familiar food protein sources. Here, we investigated the effects of edible amino acids on heat-induced aggregation of HEWP. The addition of 0.6 M arginine (Arg) completely suppressed the formation of insoluble aggregates of $1 \mathrm{mg} \mathrm{mL}-1$ HEWP following heat treatment, even at $90^{\circ} \mathrm{C}$ for $20 \mathrm{~min}$. In contrast, lysine (Lys), glycine (Gly), and sodium chloride $(\mathrm{NaCl})$ did little to suppress the aggregation of HEWP under the same conditions. SDS-PAGE indicated that Arg suppresses the thermal aggregation of almost all types of HEWP at $1 \mathrm{mg} \mathrm{mL}-1$. However, Arg did not suppress the thermal aggregation of HEWP at concentrations $\geq 10 \mathrm{mg} \mathrm{mL}^{-1}$ and prompted the formation of aggregates. Transmission electron micrographs revealed a high-density structure of unfolded proteins in the presence of Arg. These results indicate that Arg exerts a greater suppressive effect on a protein mixture, such as HEWP, than on a single model protein. These observations may propose Arg as a safe and reasonable additive to HEWP for the elimination of microorganisms by allowing an increase in sterilization temperature. 


\section{Graphical abstract}

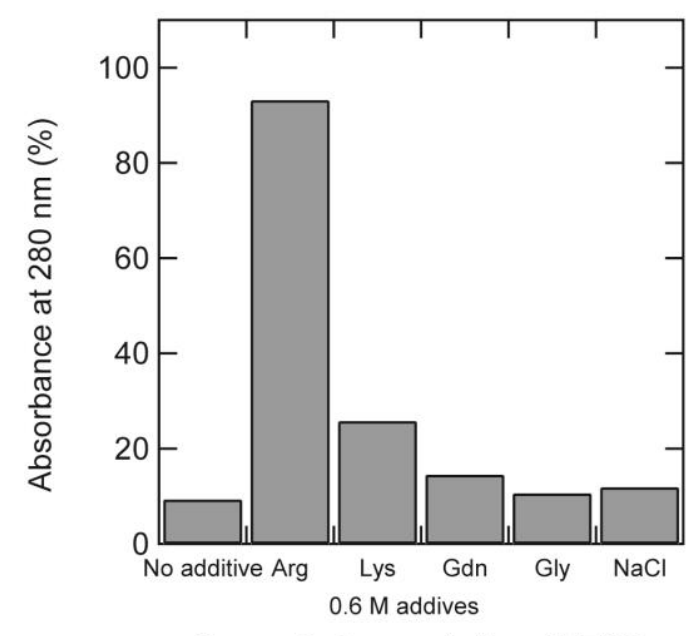

Supernatant concentration of HEWP after heat treatment

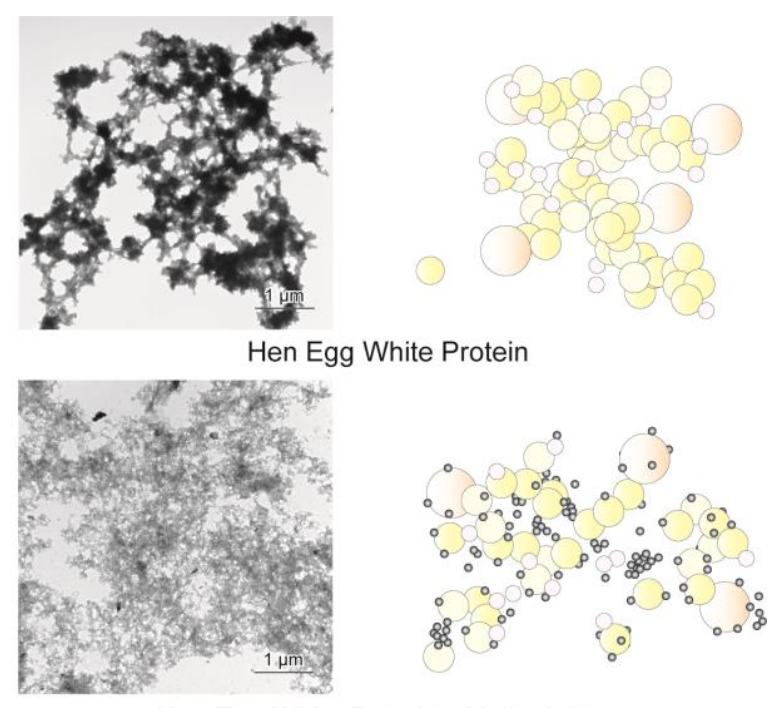

Hen Egg White Protein with Arginine

Keywords: hen egg white protein, thermal aggregation, arginine, protein mixture, safe sterilization

Chemical compounds: Chemical compounds used in this study.

L-Arginine hydrochloride (PubChem CID: 66250); L-Lysine hydrochloride (PubChem CID: 69568);

Guanidine hydrochloride (PubChem CID: 10481); Glycine (PubChem CID: 750); Sodium chloride

(PubChem CID: 5234) 


\section{Introduction}

Hen egg white protein (HEWP) is one of the most familiar protein sources in foods because of its low cost and ease of use in various food processing applications. Over the last several decades, there have been many advances in our understanding of the protein science of HEWP, such as its foaming and gelling properties (Handa, Takahashi, Kuroda, \& Froning, 1998; Liu et al., 2013; Mine, 1995, 1996; Raikos, Campbell, \& Euston, 2007; Van der Plancken, Van Loey, \& Hendrickx, 2007). In the food industry, the control of thermal aggregation plays an important role in sterilization of HEWP. For example, it is possible to make processed foods containing HEWP safer by eliminating Salmonella using heat treatment at high temperatures (Mizutani, Chen, Yamasita, Hirose, \& Aibara, 2006). However, unfavorable aggregates of HEWP made during the heat sterilization make problems by accumulating in the heat tube. Because HEWP has an unstable structure, unfavorable aggregates of HEWP formed easily by external stress, such as $\mathrm{pH}$ change ,mechanical vibration, and especially heat treatment (Csaba et al., 2010; Ferreira, Hofer, \& Raemy, 1997; Mine, Noutomi, \& Haga, 1990). Recently, it was reported that chaotropic ions prevented the thermal aggregation of HEWP (Iwashita, Inoue, Handa, \& Shiraki, 2015). These previous reports supported the rather simple application of inorganic salts in the Hofmeister series as additives to prevent the thermal aggregation of protein. However, it is also difficult to use large amounts of inorganic salts in food material because of their toxicity to human.

Arginine is a naturally occurring amino acid with a molecular weight of 174.2 Da. Arg has a guanidinium group on the side chain with the most basic isoelectric point of about $\mathrm{pH} 10.8$. Arg has been applied to solution sciences and industries, e.g., for increasing solubility of poorly soluble compounds, such as drug substances of alkyl gallates (Ariki, Hirano, Arakawa, \& Shiraki, 2011; 
Hirano, Kameda, Arakawa, \& Shiraki, 2010), coumarin(Hirano, Arakawa, \& Shiraki, 2008), caffeic acid (Hirano, Kameda, Shinozaki, Arakawa, \& Shiraki, 2013), and an unfolded protein (Reddy K., Lilie, Rudolph, \& Lange, 2005); viscosity control of pharmaceutical proteins (Inoue, Takai, Arakawa, \& Shiraki, 2014a, 2014b); adsorption control of proteins onto a solid surface (Hirano, Maruyama, Shiraki, Arakawa, \& Kameda, 2014; Shikiya, Tomita, Arakawa, \& Shiraki, 2013); improvement of protein refolding (Buchner \& Rudolph, 1991; Tsumoto et al., 1998; Umetsu et al., 2003); solubilization of porcine myosin (Takai, Yoshizawa, Ejima, Arakawa, \& Shiraki, 2013); and protein crystallization (Ito et al., 2011). In particular, the potential to suppress protein aggregation is one of the major applications of Arg as a solution additive (Das et al., 2007; Golovanov, Hautbergue, Wilson, \& Lian, 2004; Sharma, Verma, Singh, Korpole, \& Ashish, 2016; Shiraki et al., 2004; Shiraki, Kudou, Fujiwara, Imanaka, \& Takagi, 2002). The molecular mechanism underlying the activities of Arg as a solution additive is simple: (1) unique interactions between the guanidinium groups of Arg with the aromatic rings on protein, so-called cation $-\pi$ interactions (Arakawa \& Kita, 2014; Shiraki, Tomita, \& Inoue, 2016) as well as (2) electrostatic interaction by both charged $\alpha$-amino group and guanidinium group (Miyatake, Yoshizawa, Arakawa, \& Shiraki, 2016).

Here, the use of Arg for prevention of heat-induced aggregation and gelation of HEWP from the viewpoint of industrial application is reported. To elucidate the molecular mechanism underlying the effects of Arg, the effects of several amino acids and salts were compared. The results of this manuscript may provide a safe sterilization method for the elimination of Salmonella in egg white components of food.

\section{Materials and Method}




\subsection{Materials}

Guanidine hydrochloride (Gdn, PubChem CID: 10481), L-arginine hydrochloride (Arg, PubChem CID: 66250), L-lysine hydrochloride (Lys, PubChem CID: 69568), glycine (Gly, PubChem CID: 750), magnesium chloride ( $\mathrm{MgCl}_{2}$, PubChem CID: 5360315), disodium hydrogen phosphate (PubChem CID: 24203), and sodium dihydrogen phosphate (PubChem CID: 23672064) were obtained from Wako Pure Chemical Industries Ltd. (Osaka, Japan). Sodium chloride (NaCl, PubChem CID: 5234) and 2-[4-(2-hydroxyethyl)-1-piperazinyl]ethanesulfonic acid (HEPES, PubChem CID: 23831) were obtained from Nacalai Tesque (Kyoto, Japan).

\subsection{Preparation of hen egg white proteins}

Freeze-dried HEWP was prepared as described previously (Iwashita et al., 2015). Briefly, HEWP was diluted with an equal volume of distilled water, stirred gently with a magnetic stirrer for 1 hour at $4^{\circ} \mathrm{C}$, and dialyzed using a $1000 \mathrm{MW}$ cut-off dialysis tube against distilled water with four changes at $4^{\circ} \mathrm{C}$ to remove small molecular weight compounds and salts. The samples were then centrifuged at $10000 \times \mathrm{g}$ for $30 \mathrm{~min}$ to remove undesirable large aggregates for spectroscopic analysis in the following experiments. The protein content of HEWP after centrifugation was almost identical to that of the original sample. The supernatant was freeze-dried and used for further experiments.

\subsection{Thermal aggregation of hen egg white proteins and determination of concentration of protein}

HEWP solution was prepared by dissolving the freeze-dried HEWP in $10 \mathrm{mM} \mathrm{MgCl}_{2}$ and $20 \mathrm{mM}$ HEPES buffer with various concentrations of additives. The concentration of HEWP was 
adjusted to $1-100 \mathrm{mg} / \mathrm{mL}$. Thereafter, the $\mathrm{pH}$ was adjusted to 7.4 . Aliquots $(80 \mu \mathrm{L})$ of each sample were placed in $200-\mu \mathrm{L}$ microtubes. Then, the samples were heated using a temperature control system (GeneAtlasG; Astec, Fukuoka, Japan). Following heat treatment, all samples were centrifuged at $15000 \times g$ for $20 \mathrm{~min}$ at $25^{\circ} \mathrm{C}$. The concentration of supernatant was calculated by measuring the absorbance at $280 \mathrm{~nm}$ using a spectrophotometer (ND-1000; NanoDrop Technologies, Inc., Wilmington, DE). The light at the wavelength of $280 \mathrm{~nm}$ is absorbed by tryptophan, tyrosine, and phenylalanine in the protein, and it is used to measure the concentration of protein (Pace, Vajdos, Fee, Grimsley, \& Gray, 1995). The relative absorbance $\left(A / A_{0} \times 100\right)$ was plotted in the figures: $A$ and $A_{0}$, each represents the absorbance at $280 \mathrm{~nm}$ of supernatant samples after and before heat treatment, respectively.

\subsection{Sodium dodecyl sulfate-polyacrylamide gel electrophoresis}

The supernatants of each sample were dissolved in $62.5 \mathrm{mM}$ Tris- $\mathrm{HCl}(\mathrm{pH}$ 6.8) loading buffer containing 5\% (v/v) 2-mercaptoethanol, 2\% (w/v) sodium dodecyl sulfate (SDS), and 5\% $(\mathrm{w} / \mathrm{v})$ sucrose. The proteins in the samples were completely denatured by allowing them to stand undisturbed overnight at room temperature. Next, the samples and molecular weight marker (Precision Plus Protein Dual Xtra Standards; Bio-Rad, Hercules, CA) were loaded onto a 5\%-20\% gradient gel (e-PAGEL; ATTO Co., Tokyo, Japan). Following electrophoresis, the gel was stained using silver nitrate (Kato, Oda, Yamanaka, Matsudomi, \& Kobayashi, 1985).

\subsection{Size exclusion chromatography}

Soluble aggregates of HEWP were examined by high-performance liquid chromatography 
(HPLC) (Shimadzu, Kyoto, Japan) using a system consisting of a degasser (DGU-20A3), a pump (LC-10AT), an auto injector (SIL-10AXL), a column oven (CTO-10A), a UV-vis detector (SPD-10AV), and a system controller (SCL-10Avp) with a size exclusion column $(3 \mu \mathrm{m}, 300 \mathrm{~mm} \times$ 7.8 mm i.d., Yarra SEC 3000; Phenomenex, Torrance, CA). Isocratic HPLC was conducted with a flow rate of $1.0 \mathrm{~mL} \mathrm{~min}{ }^{-1}$ at $30^{\circ} \mathrm{C}$ using $200 \mathrm{mM}$ Arg, $50 \mathrm{mM}$ HEPES buffer (pH 7.4). Samples of $100 \mu \mathrm{L}$ were loaded into the column. The absorbance was monitored at $280 \mathrm{~nm}$.

\subsection{Dynamic light scattering}

dynamic light scattering analysis was performed with a Malvern Zetasizer Nano ZS (ZEN3600; Malvern Instruments, Malvern, UK), equipped with a $4 \mathrm{~mW} \mathrm{He-Ne} \mathrm{laser} \mathrm{and} \mathrm{at} \mathrm{a} \lambda$ of $633 \mathrm{~nm}$. Measurement was performed at a scattering angle of $173^{\circ}$ from the incident beam, and the particle diameter distribution in intensity was calculated by averaging from 20 to 40 measurements. DLS experiments were performed at $25^{\circ} \mathrm{C}$ with a quartz cuvette. An aliquot of $200 \mu \mathrm{L}$ of sample was added to the cuvette.

\subsection{Transmission electron microscopy}

Transmission electron microscopy (TEM) images of HEWP aggregates were examined using a transmission electron microscope (H7650; Hitachi, Tokyo, Japan) with an acceleration voltage of $80 \mathrm{kV}$ as follows. HEWP samples $\left(1 \mathrm{mg} \mathrm{mL}^{-1}\right)$ containing $10 \mathrm{mM} \mathrm{MgCl} 2$ and $20 \mathrm{mM}$ HEPES (pH 7.4) were heated at $90^{\circ} \mathrm{C}$ for $30 \mathrm{~min}$ in the presence or absence of $0.6 \mathrm{M}$ additives (Arg, Lys, Gly, Gdn, and $\mathrm{NaCl}$ ). The heated samples were diluted 100 -fold in water, and $30 \mu \mathrm{L}$ of diluted sample was negatively stained with $30 \mu \mathrm{L}$ of $2 \%(\mathrm{w} / \mathrm{v})$ silicon tungstate solution. Approximately 4 $\mu \mathrm{L}$ of the stained solution was placed on a 150-mesh copper grid covered with a carbon-coated 
hydrophilic film. The solution on the grid was allowed to dry for 2 days.

\section{Results}

\subsection{Suppression of thermal aggregation by Arg}

It was investigated whether Arg could suppress the thermal aggregation of HEWP as compared with the control additives. Arg has a composition of (i) basic amino acid, (ii) guanidinium group side chain, and (iii) aliphatic chain. The control additives were selected as follows (Fig. 1). Guanidine (Gdn) has a similar structure to the guanidinium group of Arg. It is possible to confirm the presence of $\pi$-cation interaction and electrostatic interaction between protein and additive by comparing Arg and Gdn. Glycine (Gly) is the smallest amino acid included in Arg main chain. It is possible to confirm the role of main chain of Arg by comparing with Gly. Lysine (Lyts) has an amino acid with a positively charged side chain, which is similar structure to Arg. Thus, it is possible to confirm the role of guanidinium group of Arg by comparing with amino group. Sodium chloride $(\mathrm{NaCl})$ affects to proteins electrostatically, similarly to $\mathrm{Arg}-\mathrm{HCl}$ in solution. It is possible to confirm the role of Arg as a monovalent ion by comparing with $\mathrm{NaCl}$. Fig. 2 shows the thermal aggregation of $1 \mathrm{mg} \mathrm{mL} \mathrm{m}^{-1} \mathrm{HEWP}$ in the presence of $0.6 \mathrm{M}$ amino acids and salts. The vertical axis represents the relative absorbance of protein in the supernatant after centrifugation. HEWP in the absence of additives was rapidly aggregated by heat treatment at $90^{\circ} \mathrm{C}$ for several min (Fig. 2A). The remaining $10 \%$ absorbance during heat treatment was attributed to heat-resistant ovomucoid protein (Handa et al., 1998; Stadelman, Newkirk, \& Newby, 1995). In contrast, the absorbance of HEWP with 0.6 M Arg was $>90 \%$ maintained, even after heat treatment for $30 \mathrm{~min}$. In the presence of Lys, HEWP was gradually aggregated with heating time; the residual absorbance of the sample with Lys was 30\% 
after heat treatment at $90^{\circ} \mathrm{C}$ for $30 \mathrm{~min}$. The other additives, Gdn, Gly, and $\mathrm{NaCl}$, did not suppress the heat-induced aggregation of HEWP. Thus, the outstanding effect of Arg as an aggregation suppressor toward HEWP resulted from a combination of chemical structural properties, involving the amino acid, guanidinium group, and salt.

Fig. 2B shows the absorbance of $1 \mathrm{mg} \mathrm{mL}^{-1}$ HEWP after heat treatment at various temperatures for $30 \mathrm{~min}$. The samples without additives aggregated in two stages at approximately $55^{\circ} \mathrm{C}$ and $70^{\circ} \mathrm{C}$. Above $80^{\circ} \mathrm{C}$, almost all proteins consisting of HEWP aggregated, and only $10 \%$ absorbance by ovomucoid remained. On the other hand, the absorbance of HEWP with $0.6 \mathrm{M}$ Arg was maintained at $>90 \%$, even at $90^{\circ} \mathrm{C}$. Lys was the second best additive for the thermal aggregation of HEWP, although the effect on aggregation suppression of Lys was clearly lower than that of Arg. In the presence of $\mathrm{Gdn}, \mathrm{Gly}$, and $\mathrm{NaCl}$, the aggregation temperatures were lower than those in the presence of Arg and Lys. To more clearly illustrate the data, the aggregation profile with Gdn showed one stage at around $55^{\circ} \mathrm{C}$ to $65^{\circ} \mathrm{C}$; the residual absorbance of HEWP with Gdn $>80^{\circ} \mathrm{C}$ was approximately $30 \%$. In the presence of $\mathrm{NaCl}$, the starting aggregation temperatures of HEWP were increased to $70^{\circ} \mathrm{C}$, similar to the profile of Lys.

To elucidate the limitations of Arg, the protein concentration dependence of the thermal aggregation of HEWP at $90^{\circ} \mathrm{C}$ for $30 \mathrm{~min}$ in the presence or absence of Arg was investigated (Fig. 3). The samples without additive showed approximately $10 \%$ absorbance of HEWP at all protein concentrations examined following heat treatment. In the presence of $0.6 \mathrm{M}$ and $1.2 \mathrm{M} \mathrm{Arg}$, the residual soluble concentrations of HEWP decreased with a sigmoid shape with increasing HEWP concentration. The suppressive effect of Arg on the thermal aggregation of HEWP was diminished at $>10 \mathrm{mg} \mathrm{mL}^{-1}$. 


\subsection{SDS-PAGE for identifying soluble proteins after heat treatment}

To determine the aggregative tendencies of individual proteins, we analyzed the soluble HEWP after heat treatment by SDS-PAGE (Fig. 4). The SDS-PAGE of the Gdn sample could not be performed due to the formation of an insoluble salt with SDS. Clear bands were obtained that could distinguish a dozen major proteins in HEWP (Fig. 4). Table 1 summarizes the characteristics of four major proteins for references. The temperatures in Table 1 define as the temperature at which aggregation began as determined in Fig. 4. In the absence of additives, purified ovotransferrin, lysozyme, and ovalbumin proteins were aggregated by heat treatment at $60^{\circ} \mathrm{C}, 65^{\circ} \mathrm{C}$, and $70^{\circ} \mathrm{C}$, respectively. The temperatures at which aggregation of lysozyme in HEWP began as determined by SDS-PAGE were lower than those of lysozyme alone (Fig. S1). These observations suggest that proteins in a mixture are prone to form aggregates than the purified protein in solution. The solution additives influenced the temperature at which aggregation began for all proteins. The differences could be summarized as follows: (i) Arg suppresses the aggregation of all types of HEWP effectively at $<90^{\circ} \mathrm{C}$; (ii) Lys and $\mathrm{NaCl}$ suppress the aggregation of ovotransferrin and lysozyme mainly, but not ovalbumin; (iii) Gly suppresses the aggregation of all types of HEWP uniformly but not effectively.

\subsection{Measurement of soluble aggregates by SDS-PAGE, HPLC, and DLS}

Large-scale soluble aggregates were formed when HEWP was heated at $65^{\circ} \mathrm{C}$ for $30 \mathrm{~min}$ in the presence of $\mathrm{NaCl}$, Lys, and especially Arg (Fig. 4). The corresponding band was not observed when HEWP was heated at $65^{\circ} \mathrm{C}$ for 30 min without these salts. These results suggest that Arg helps 
in the formation of soluble aggregates of HEWP in contrast to its effect in hampering the formation of insoluble aggregates of HEWP. To verify this suggestion, it was investigated whether Arg promotes formation of soluble aggregates of HEWP by SDS-PAGE, HPLC, and DLS.

Fig. 5A shows the results of SDS-PAGE analysis of HEWP. Here, MIX is a mixed sample containing three purified proteins, i.e., lysozyme (LYZ), ovalbumin (OVA), and ovotransferrin (OVT) at a weight ratio of 2:32:7, which are the major components of HEWP. After heat treatment at $65^{\circ} \mathrm{C}$ for $30 \mathrm{~min}$, HEWP with Arg showed a band corresponding to soluble aggregates. In contrast, no such band was observed after heat treatment of HEWP without Arg. Similarly, MIX samples did not show the band corresponding to the soluble aggregate in the presence or absence of Arg as an additive. These results indicated that Arg induces soluble aggregation of minor proteins in egg white. Fig. 5B shows the results of analyses of the soluble aggregates by size exclusion chromatography of HEWP with Arg as an additive. HEWP with Arg was heated at $65^{\circ} \mathrm{C}$ for $30 \mathrm{~min}$, and the sample was centrifuged and subjected to column chromatography. As expected, a broad peak was detected at a retention time of 5-9, corresponding to the soluble aggregates only with Arg. Fig. 5C shows the results of dynamic light scattering analysis of HEWP. The soluble aggregates $>100 \mathrm{~nm}$ in diameter were formed only when HEWP was heated with Arg. The peak $<1 \mathrm{~nm}$ seems to correspond to arginine molecules and that at $20 \mathrm{~nm}$ corresponds to overlap of the two peaks of monomer and small soluble aggregates formed by thermal aggregation of monomers. These data indicate that Arg assists HEWP to form soluble aggregates after heat treatment at $65^{\circ} \mathrm{C}$ for $30 \mathrm{~min}$.

\subsection{Transmission electron microscopy}

Fig. 6 shows the aggregate structures of HEWP monitored by TEM in the presence or 
absence of additives. The thermal aggregates of HEWP without additives showed large, dense structures (Fig. 6A). In contrast, the aggregates were fine and sparse in the presence of Arg (Fig. 6B). In the presence of Gdn, the particles size was fine, similar to the case of Arg, but dense aggregates were formed, similar to those formed without additives (Fig. 6D). The aggregates formed in the presence of Lys, Gly, and $\mathrm{NaCl}$ were similar to those formed in the absence of additives (Fig. 6C, E, and F). It was expected that only a few aggregates were observed in the samples with Arg, which was different from the case with the other additives. These results indicated that Arg actually influences the protein aggregate structure to be more fine and sparse, in addition to suppressing the aggregation of HEWP.

\section{Discussion}

\subsection{Mechanisms of action of Arg in the protein mixture milieu}

This study was performed to investigate application of Arg as an additive to control the thermal aggregation of HEWP. The results showed that Arg prevented thermal aggregation of HEWP. The optimum concentration of Arg for the effect on thermal aggregation of HEWP was approximately $0.6 \mathrm{M}$, which was similar to the data obtained for single model proteins in previous experiment (Arakawa et al., 2007; Das et al., 2007; Miyatake et al., 2016). In these experiments, Lys and $\mathrm{NaCl}$ mainly prevented the aggregation of ovotransferrin and lysozyme (Figs. $4 \mathrm{C}$ and E), while Gly mainly prevented the aggregation of ovalbumin (Figs. 2, and 4D). The former was attributed to the electrostatic charge, while the latter was due to the main chain structure.

Protein aggregation is generally prevented by the additive that can interact with the protein surface. The molecular mechanism how Arg interacts with HEWP and prevents the thermal 
aggregation of HEWP as a solvent additive could be briefly summarized as follows (Shiraki et al., 2016): (i) Arg prevents the chemical modification of protein such as deamidation of side chains of Asparagine and Glutamine (Tomita, Nagasaki, \& Shiraki, 2012; Tomita \& Shiraki, 2011); (ii) Arg causes steric hindrance by sandwiched between proteins, so called gap effect (Baynes, Wang, \& Trout, 2005; Shukla \& Trout, 2010; Vagenende, Han, Mueller, \& Trout, 2013); (iii) Arg interacts with proteins by specific interactions, such as cation $-\pi$ interactions, electrostatic interactions, hydrophobic interactions, and hydrogen bonding (Petrauskas, Maximowitsch, \& Matulis, 2015; Shah, Shaikh, Peng, \& Rajagopalan, 2011); (iv) Arg increases the surface tension of water. This results in the inhibition of protein aggregation as a solvent effect (Arakawa et al., 2007; Arakawa \& Timasheff, 1983); and finally (v) Arg is one of the salts in aqueous solution at neutral pH (Inoue et al., 2014a). It was postulated that all of the above mechanisms affect protein aggregation by cooperating or competing in HEWP systems, but the effectiveness of each mechanism varies as follows. First, HEWP solution contains various types of charged proteins. Thus, the salt effect (type v) may have little effect as an aggregation suppressor. Indeed, $\mathrm{NaCl}$ did not suppress the aggregation of HEWP compared with Arg (Fig. 2). Similarly, the gap effect (type ii) may be weak because HEWP contains proteins of various sizes and types. On the other hand, the suppression of chemical modification (type i) is one of the most plausible effects of Arg as an additive on thermal degradation because chemical reactions do not depend on the types of proteins present (Tomita \& Shiraki, 2011). Similarly, specific interaction between Arg and protein (type iii) plays an important role in the aggregation of protein mixtures because almost all proteins contain aromatic amino acid residues. There has been increasing interest in the food industry on research regarding protein mixtures (Lam \& Nickerson, 2014; Loveday, Ye, Anema, \& Singh, 2013; Paraskevopoulou, Amvrosiadou, 
Biliaderis, \& Kiosseoglou, 2014). Arg could be a good additive because it is a non-toxic, stable, and inexpensive amino acid that could interact with various compounds.

\subsection{Collaborative aggregation in HEWP}

HEWP contains various proteins that interact with each other (Lechevalier et al., 2005; Nakai \& Kason, 1974). Under the mixed protein solution, the unfolded proteins are prone to form aggregates (Iwashita, Handa, \& Shiraki, 2017; Matsudomi, Yamamura, \& Kobayashi, 1986; Wu, Zhao, Yang, \& Yan, 2015). Briefly, electrostatic repulsions are the most dominant factors in a kind of protein solution because all proteins possess intrinsic isoelectric point (pI). Thus, the electrostatic repulsions between protein molecules compete the hydrophobic attraction, leading to inhibit the aggregate formation. By contrast, mixed proteins with various pIs attract each other by electrostatic as well as hydrophobic attractions, which is prone to form aggregates. Each protein co-existing in the same environment was shown to be prone to form aggregates at a lower temperature than the pure proteins themselves (Fig. 4, Fig. S1, Table 1). Lysozyme in HWEP is prone to aggregate than lysozyme alone. Since lysozyme is a positively charged protein at neutral $\mathrm{pH}$, it tends to bind with other negatively charged and previously denatured proteins such as ovalbumin and ovotransferrin. Similar comparisons between single and protein mixture were studied by Johnson et al. (Johnson \& Zabik, 1981). This supports the occurrence of collaborative aggregation in HEWP. Such collaborative aggregation theory can also explain the changes in the molecular mechanism of HEWP aggregation between low and high concentrations of HEWP in the presence of additives because higher concentrations facilitate protein aggregation (Iwashita et al., 2015; Tomita, Yoshikawa, \& Shiraki, 2011). 


\subsection{Safe sterilization by Arg}

Arg supports the formation of soluble aggregates of HEWP in contrast to its effect in preventing the formation of insoluble aggregates. However, we emphasize that small aggregate formation is much less problematic during the sterilization process than large aggregate formation. This is because the major problems encountered in sterilizing eggs are triggered only by large aggregates. The accumulated large aggregates hamper heat conduction in the manufacturing of HEWP, leading to a decrease in sterilization efficiency. In contrast, it is thought that the soluble aggregates can avoid these problems during the sterilization process. Rather, it was reported that the presence of soluble aggregates improves food quality by enhancing the texture of soy proteins and thermal and storage stability of beverages (Jian et al., 2016; Ryan \& Foegeding, 2015).

\section{Conclusion}

This study showed that Arg effectively suppresses the thermal aggregation of HEWP below $3 \mathrm{mg} \mathrm{mL}^{-1}$. Mixed proteins are more prone to aggregation due to thermal stress than pure proteins, and Arg prevents the thermal aggregation of these mixed proteins. Such experimental data using crude protein mixtures provide new insight into the effect of Arg as an aggregation suppressor. Furthermore, Arg alters the gel properties of HEWP. These observations suggest that Arg may be applied to control the foaming and gelling properties of HEWP. On the other hand, Arg unexpectedly accelerated the formation of small and soluble aggregates. This study suggested the potential application of Arg as an additive to control insoluble aggregates and the soluble state of HEWP. 


\section{Acknowledgments}

This work was partly supported financially by the Faculty of Pure and Applied Sciences, University of Tsukuba, JSPS KAKENHI Grant Numbers $15 \mathrm{H} 03583$ and 15K13812 and R\&D Division, Kewpie Corporation. We thank Dr. Atsushi Hirano and Dr. Takeshi Tanaka (Nanomaterials Research Institute, National Institute of Advanced Industrial Science and Technology) for DLS analyses. 


\section{References}

Arakawa, T., Ejima, D., Tsumoto, K., Obeyama, N., Tanaka, Y., Kita, Y., \& Timasheff, S. N. (2007). Suppression of protein interactions by arginine: A proposed mechanism of the arginine effects. Biophysical Chemistry, 127(1-2), 1-8. https://doi.org/10.1016/j.bpc.2006.12.007

Arakawa, T., \& Kita, Y. (2014). Multi-Faceted Arginine: Mechanism of the Effects of Arginine on Protein. Current Protein and Peptide Science, 15(6), 608-620.

Arakawa, T., \& Timasheff, S. N. (1983). Preferential interactions of proteins with solvent components in aqueous amino acid solutions. Archives of Biochemistry and Biophysics, 224(1), 169-177. https://doi.org/10.1016/0003-9861(83)90201-1

Ariki, R., Hirano, A., Arakawa, T., \& Shiraki, K. (2011). Arginine increases the solubility of alkyl gallates through interaction with the aromatic ring. Journal of Biochemistry, 149(4), 389394. https://doi.org/10.1093/jb/mvr004

Baynes, B. M., Wang, D. I. C., \& Trout, B. L. (2005). Role of arginine in the stabilization of proteins against aggregation. Biochemistry, 44(12), 4919-4925. https://doi.org/10.1021/bi047528r

Buchner, J., \& Rudolph, R. (1991). Renaturation, purification and characterization of recombinant Fab-fragments produced in Escherichia coli. Nature Biotechnology, 9(2), 157-162. https://doi.org/10.1038/nbt0291-157

Csaba, N., Kinga, H., Arpad, D., Lzszlo, F., Klara, P.-H., \& Csaba, B. (2010). Calorimetric study of changes induced by preservatives in liquid egg products. Polish Journal of Food and Nutrition $\quad$ Sciences, $\quad 60(4) . \quad$ Retrieved from http://yadda.icm.edu.pl/yadda/element/bwmeta1.element.agro-7c6da904-bf8c-49c5-ab96-3f 0a836c7bbd 
Das, U., Hariprasad, G., Ethayathulla, A. S., Manral, P., Das, T. K., Pasha, S., ... Srinivasan, A. (2007). Inhibition of protein aggregation: supramolecular assemblies of arginine hold the key. PLoS ONE, 2(11), e1176. https://doi.org/10.1371/journal.pone.0001176

Ferreira, M., Hofer, C., \& Raemy, A. (1997). A calorimetric study of egg white proteins. Journal of Thermal Analysis and Calorimetry, 48(3), 683-690. https://doi.org/10.1007/BF01979514

Golovanov, A. P., Hautbergue, G. M., Wilson, S. A., \& Lian, L.-Y. (2004). A simple method for improving protein solubility and long-term stability. Journal of the American Chemical Society, 126(29), 8933-8939. https://doi.org/10.1021/ja049297h

Guérin-Dubiard, C., Pasco, M., Mollé, D., Désert, C., Croguennec, T., \& Nau, F. (2006). Proteomic analysis of hen egg white. Journal of Agricultural and Food Chemistry, 54(11), 3901-3910. https://doi.org/10.1021/jf0529969

Handa, A., Takahashi, K., Kuroda, N., \& Froning, G. W. (1998). Heat-induced egg white gels as affected by pH. Journal of Food Science, 63(3), 403-407. https://doi.org/10.1111/j.1365-2621.1998.tb15752.x

Hirano, A., Arakawa, T., \& Shiraki, K. (2008). Arginine increases the solubility of coumarin: comparison with salting-in and salting-out additives. Journal of Biochemistry, 144(3), 363369. https://doi.org/10.1093/jb/mvn078

Hirano, A., Kameda, T., Arakawa, T., \& Shiraki, K. (2010). Arginine-assisted solubilization system for drug substances: solubility experiment and simulation. The Journal of Physical Chemistry B, 114(42), 13455-13462. https://doi.org/10.1021/jp101909a

Hirano, A., Kameda, T., Shinozaki, D., Arakawa, T., \& Shiraki, K. (2013). Molecular dynamics simulation of the arginine-assisted solubilization of caffeic acid: intervention in the 
interaction. The Journal of Physical Chemistry B, 117(25), 7518-7527. https://doi.org/10.1021/jp401609p

Hirano, A., Maruyama, T., Shiraki, K., Arakawa, T., \& Kameda, T. (2014). Mechanism of protein desorption from 4-mercaptoethylpyridine resins by arginine solutions. Journal of Chromatography A, 1373, 141-148. https://doi.org/10.1016/j.chroma.2014.11.032

Inoue, N., Takai, E., Arakawa, T., \& Shiraki, K. (2014a). Arginine and lysine reduce the high viscosity of serum albumin solutions for pharmaceutical injection. Journal of Bioscience and Bioengineering, 117(5), 539-543. https://doi.org/10.1016/j.jbiosc.2013.10.016

Inoue, N., Takai, E., Arakawa, T., \& Shiraki, K. (2014b). Specific decrease in solution viscosity of antibodies by arginine for therapeutic formulations. Molecular Pharmaceutics, 11(6), 18891896. https://doi.org/10.1021/mp5000218

Ito, L., Shiraki, K., Matsuura, T., Okumura, M., Hasegawa, K., Baba, S., ... Kumasaka, T. (2011). High-resolution X-ray analysis reveals binding of arginine to aromatic residues of lysozyme surface: implication of suppression of protein aggregation by arginine. Protein Engineering Design and Selection, 24(3), 269-274. https://doi.org/10.1093/protein/gzq101

Iwashita, K., Handa, A., \& Shiraki, K. (2017). Co-aggregation of ovalbumin and lysozyme. Food Hydrocolloids, 67, 206-215. https://doi.org/10.1016/j.foodhyd.2017.01.014

Iwashita, K., Inoue, N., Handa, A., \& Shiraki, K. (2015). Thermal aggregation of hen egg white proteins in the presence of salts. The Protein Journal, 34(3), 212-219. https://doi.org/10.1007/s10930-015-9612-3

Jian, H., Qiao, F., Yang, P., Guo, F., Huang, X., Adhikari, B., \& Chen, J. (2016). Roles of soluble and insoluble aggregates induced by soy protein processing in the gelation of myofibrillar 
protein. International Journal of Food Science \& Technology, 51(2), 480-489. https://doi.org/10.1111/ijfs.12992

Johnson, T. M., \& Zabik, M. E. (1981). Gelation properties of albumen proteins, singly and in combination. Poultry Science, 60(9), 2071-2083. https://doi.org/10.3382/ps.0602071

Kato, A., Oda, S., Yamanaka, Y., Matsudomi, N., \& Kobayashi, K. (1985). Functional and Structural Properties of Ovomucin. Agricultural and Biological Chemistry, 49(12), 3501-3504. https://doi.org/10.1080/00021369.1985.10867297

Lam, R. S. H., \& Nickerson, M. T. (2014). The properties of whey protein -carrageenan mixtures during the formation of electrostatic coupled biopolymer and emulsion gels. Food Research International, 66, 140-149. https://doi.org/10.1016/j.foodres.2014.08.006

Lechevalier, V., Croguennec, T., Pezennec, S., Guérin-Dubiard, C., Pasco, M., \& Nau, F. (2005). Evidence for synergy in the denaturation at the air-water interface of ovalbumin, ovotransferrin and lysozyme in ternary mixture. Food Chemistry, 92(1), 79-87. https://doi.org/10.1016/j.foodchem.2004.07.006

Liu, J., Zhu, K., Ye, T., Wan, S., Wang, Y., Wang, D., ... Wang, C. (2013). Influence of konjac glucomannan on gelling properties and water state in egg white protein gel. Food Research International, 51(2), 437-443. https://doi.org/10.1016/j.foodres.2013.01.002

Loveday, S. M., Ye, A., Anema, S. G., \& Singh, H. (2013). Heat-induced colloidal interactions of whey proteins, sodium caseinate and gum arabic in binary and ternary mixtures. Food Research International, 54(1), 111-117. https://doi.org/10.1016/j.foodres.2013.06.013

Matsudomi, N., Yamamura, Y., \& Kobayashi, K. (1986). Heat-induced aggregation between ovalbumin and lysozyme. Agricultural and Biological Chemistry, 50(6), 1389-1395. 
https://doi.org/10.1080/00021369.1986.10867601

Mine, Y. (1995). Recent advances in the understanding of egg white protein functionality. Trends in $\begin{array}{llll}\text { Food Science } \quad \& \quad \text { Technology, } & 6(7), & 225-232 .\end{array}$ https://doi.org/10.1016/S0924-2244(00)89083-4

Mine, Y. (1996). Effect of pH during the dry heating on the gelling properties of egg white proteins.
Food
Research
International,
29(2),
$155-161$.

https://doi.org/10.1016/0963-9969(96)00008-7

Mine, Y., Noutomi, T., \& Haga, N. (1990). Thermally induced changes in egg white proteins. Journal of Agricultural and Food Chemistry, 38(12), 2122-2125. https://doi.org/10.1021/jf00102a004

Miyatake, T., Yoshizawa, S., Arakawa, T., \& Shiraki, K. (2016). Charge state of arginine as an additive on heat-induced protein aggregation. International Journal of Biological Macromolecules, 87, 563-569. https://doi.org/10.1016/j.ijbiomac.2016.03.015

Mizutani, K., Chen, Y., Yamasita, H., Hirose, M., \& Aibara, S. (2006). Thermostabilization of ovotransferrin by anions for pasteurization of liquid egg white. Bioscience, Biotechnology, and Biochemistry, 70(8), 1839-1845. https://doi.org/10.1271/bbb.60003

Nakai, S., \& Kason, C. M. (1974). A fluorescence study of the interactions between $\kappa$ - and as1-casein and between lysozyme and ovalbumin. Biochimica et Biophysica Acta (BBA) Protein Structure, 351(1), 21-27. https://doi.org/10.1016/0005-2795(74)90062-2

Pace, C. N., Vajdos, F., Fee, L., Grimsley, G., \& Gray, T. (1995). How to measure and predict the molar absorption coefficient of a protein. Protein Science, 4(11), 2411-2423. https://doi.org/10.1002/pro.5560041120 
Paraskevopoulou, A., Amvrosiadou, S., Biliaderis, C. G., \& Kiosseoglou, V. (2014). Mixed whey protein isolate-egg yolk or yolk plasma heat-set gels: Rheological and volatile compounds characterisation. Food Research International, $62, \quad 492-499$. https://doi.org/10.1016/j.foodres.2014.03.056

Petrauskas, V., Maximowitsch, E., \& Matulis, D. (2015). Thermodynamics of ion pair formations netween charged poly(amino acid)s. The Journal of Physical Chemistry B, 119(37), 1216412171. https://doi.org/10.1021/acs.jpcb.5b05767

Qiu, N., Ma, M., Cai, Z., Jin, Y., Huang, X., Huang, Q., \& Sun, S. (2012). Proteomic analysis of egg white proteins during the early phase of embryonic development. Journal of Proteomics, 75(6), 1895-1905. https://doi.org/10.1016/j.jprot.2011.12.037

Raikos, V., Campbell, L., \& Euston, S. R. (2007). Effects of sucrose and sodium chloride on foaming properties of egg white proteins. Food Research International, 40(3), 347-355. https://doi.org/10.1016/j.foodres.2006.10.008

Rao, Q., Rocca-Smith, J. R., \& Labuza, T. P. (2012). Moisture-induced quality changes of hen egg white proteins in a protein/water model system. Journal of Agricultural and Food Chemistry, 60(42), 10625-10633. https://doi.org/10.1021/jf302402k

Reddy K., R. C., Lilie, H., Rudolph, R., \& Lange, C. (2005). 1-Arginine increases the solubility of unfolded species of hen egg white lysozyme. Protein Science, 14(4), 929-935. https://doi.org/10.1110/ps.041085005

Ryan, K. N., \& Foegeding, E. A. (2015). Formation of soluble whey protein aggregates and their stability in beverages. Food Hydrocolloids, 43, 265-274. https://doi.org/10.1016/j.foodhyd.2014.05.025 
Shah, D., Shaikh, A. R., Peng, X., \& Rajagopalan, R. (2011). Effects of arginine on heat-induced aggregation of concentrated protein solutions. Biotechnology Progress, 27(2), 513-520. https://doi.org/10.1002/btpr.563

Sharma, P., Verma, N., Singh, P. K., Korpole, S., \& Ashish. (2016). Characterization of heat induced spherulites of lysozyme reveals new insight on amyloid initiation. Scientific Reports, 6. https://doi.org/10.1038/srep22475

Shikiya, Y., Tomita, S., Arakawa, T., \& Shiraki, K. (2013). Arginine inhibits adsorption of proteins on $\quad$ polystyrene $\quad$ surface. $\quad P L o S \quad O N E, \quad 8(8), \quad$ e70762. https://doi.org/10.1371/journal.pone.0070762

Shiraki, K., Kudou, M., Fujiwara, S., Imanaka, T., \& Takagi, M. (2002). Biophysical effect of amino acids on the prevention of protein aggregation. Journal of Biochemistry, 132(4), 591-595.

Shiraki, K., Kudou, M., Nishikori, S., Kitagawa, H., Imanaka, T., \& Takagi, M. (2004). Arginine ethylester prevents thermal inactivation and aggregation of lysozyme. European Journal of Biochemistry, 271(15), 3242-3247. https://doi.org/10.1111/j.1432-1033.2004.04257.x

Shiraki, K., Tomita, S., \& Inoue, N. (2016). Small amine molecules: solvent design toward facile improvement of protein stability against aggregation and inactivation. Current Pharmaceutical Biotechnology, 17(2), 116-125.

Shukla, D., \& Trout, B. L. (2010). Interaction of arginine with proteins and the mechanism by which it inhibits aggregation. The Journal of Physical Chemistry B, 114(42), 13426-13438. https://doi.org/10.1021/jp108399g

Stadelman, W. J., Newkirk, D., \& Newby, L. (1995). Egg science and technology, fourth edition. CRC Press. 
Takai, E., Yoshizawa, S., Ejima, D., Arakawa, T., \& Shiraki, K. (2013). Synergistic solubilization of porcine myosin in physiological salt solution by arginine. International Journal of Biological Macromolecules, 62, 647-651. https://doi.org/10.1016/j.ijbiomac.2013.09.035

Tomita, S., Nagasaki, Y., \& Shiraki, K. (2012). Different mechanisms of action of poly(ethylene glycol) and arginine on thermal inactivation of lysozyme and ribonuclease A. Biotechnology and Bioengineering, 109(10), 2543-2552. https://doi.org/10.1002/bit.24531

Tomita, S., \& Shiraki, K. (2011). Why do solution additives suppress the heat-induced inactivation of proteins? Inhibition of chemical modifications. Biotechnology Progress, 27(3), 855-862. https://doi.org/10.1002/btpr.597

Tomita, S., Yoshikawa, H., \& Shiraki, K. (2011). Arginine controls heat-induced cluster-cluster aggregation of lysozyme at around the isoelectric point. Biopolymers, 95(10), 695-701. https://doi.org/10.1002/bip.21637

Tsumoto, K., Shinoki, K., Kondo, H., Uchikawa, M., Juji, T., \& Kumagai, I. (1998). Highly efficient recovery of functional single-chain $\mathrm{Fv}$ fragments from inclusion bodies overexpressed in Escherichia coli by controlled introduction of oxidizing reagent - application to a human single-chain Fv fragment. Journal of Immunological Methods, 219(1-2), 119-129. https://doi.org/10.1016/S0022-1759(98)00127-6

Umetsu, M., Tsumoto, K., Hara, M., Ashish, K., Goda, S., Adschiri, T., \& Kumagai, I. (2003). How additives influence the refolding of immunoglobulin-folded proteins in a stepwise dialysis system spectroscopic evidence for highly efficient refolding of a single-chain Fv fragment.

Journal of Biological Chemistry, 278(11), 8979-8987. https://doi.org/10.1074/jbc.M212247200 
Vagenende, V., Han, A. X., Mueller, M., \& Trout, B. L. (2013). Protein-associated cation clusters in aqueous arginine solutions and their effects on protein stability and size. ACS Chemical Biology, 8(2), 416-422. https://doi.org/10.1021/cb300440x

Van der Plancken, I., Van Loey, A., \& Hendrickx, M. E. (2007). Foaming properties of egg white proteins affected by heat or high pressure treatment. Journal of Food Engineering, 78(4), 1410-1426. https://doi.org/10.1016/j.jfoodeng.2006.01.013

Wu, L., Zhao, W., Yang, R., \& Yan, W. (2015). Pulsed electric field (PEF)-induced aggregation between lysozyme, ovalbumin and ovotransferrin in multi-protein system. Food Chemistry, 175, 115-120. https://doi.org/10.1016/j.foodchem.2014.11.136 


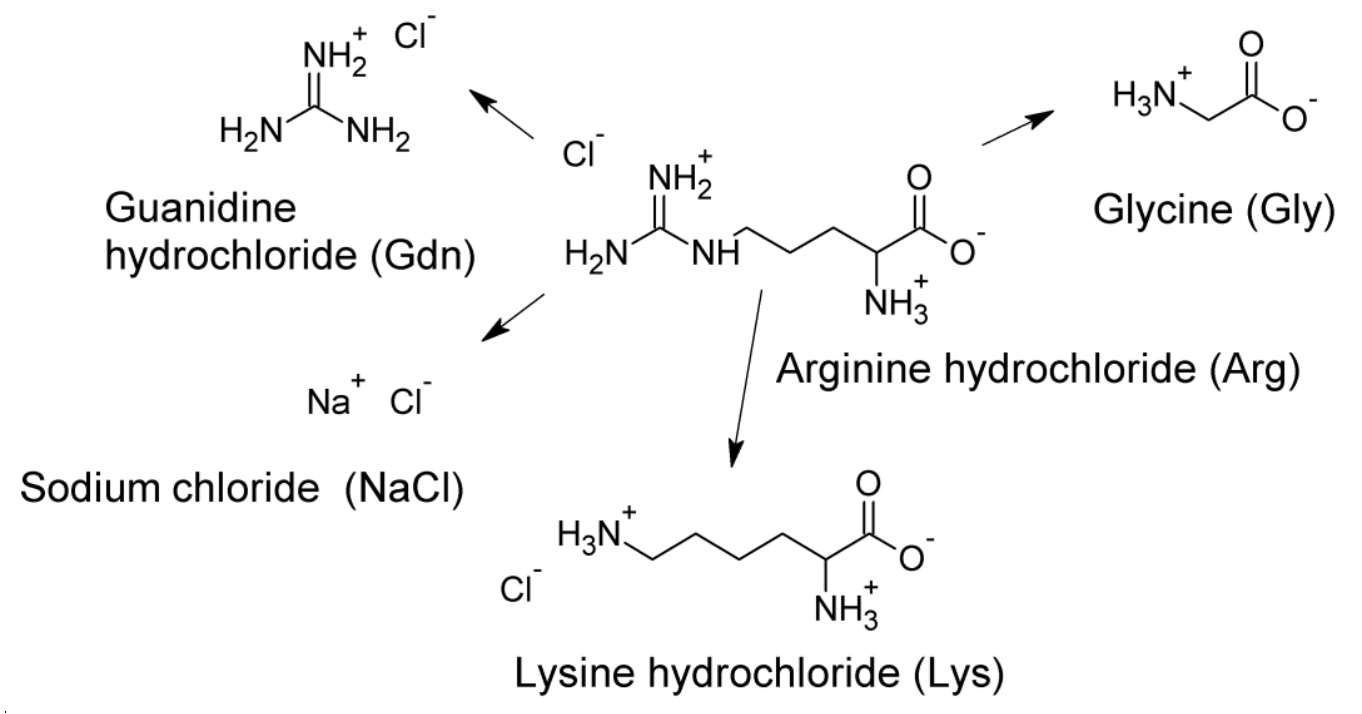

Fig. 1. Chemical structures of additives. 

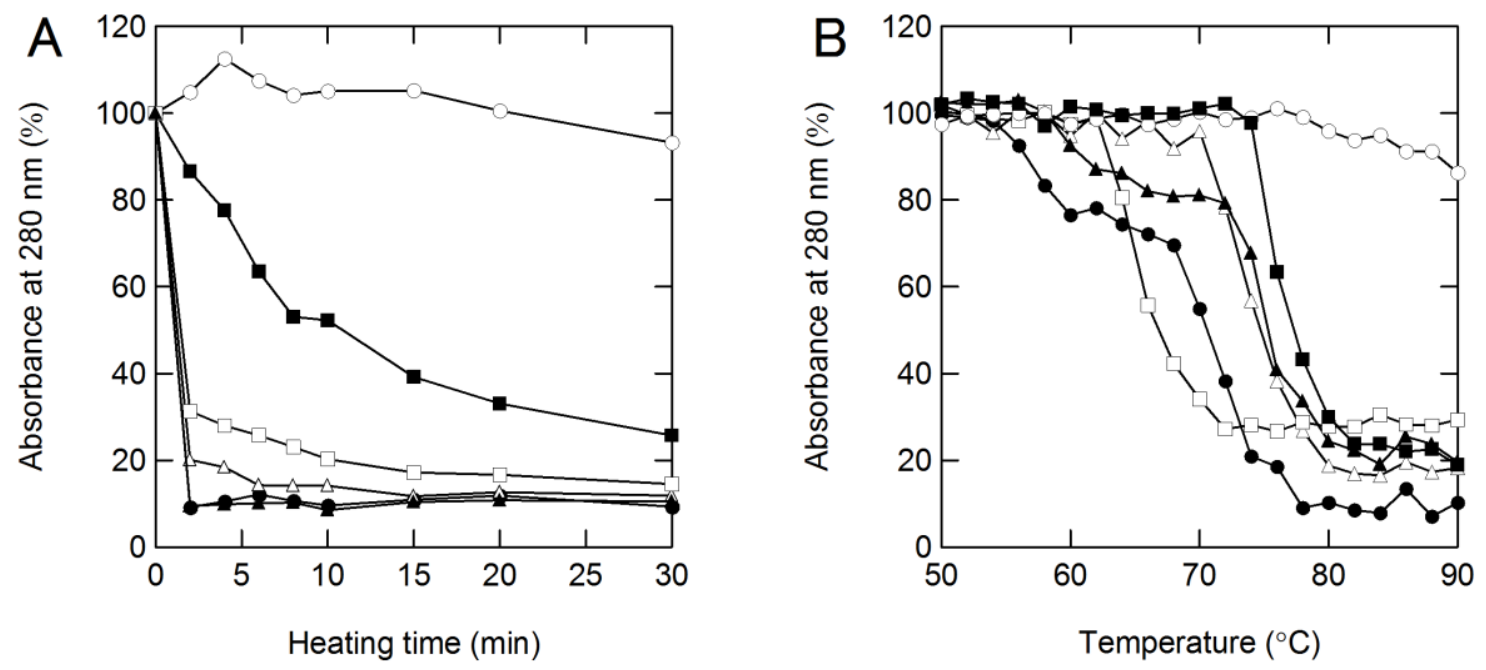

Fig. 2. Supernatant protein concentration of HEWP after heat treatment. The samples contained 0.6 M Arg (open circles, ○), Lys (closed squares, $\bullet$ ), Gdn (open squares, $\square$ ), Gly (closed triangles, $\mathbf{\Delta}$ ), $\mathrm{NaCl}$ (open triangles, $\triangle$ ), or no additive (closed circles, •) with $1 \mathrm{mg} \mathrm{mL}^{-1}$ HEWP. (A) The samples were heated at $90^{\circ} \mathrm{C}$ for various periods. (B) The samples were heated to various temperatures for $30 \mathrm{~min}$. 


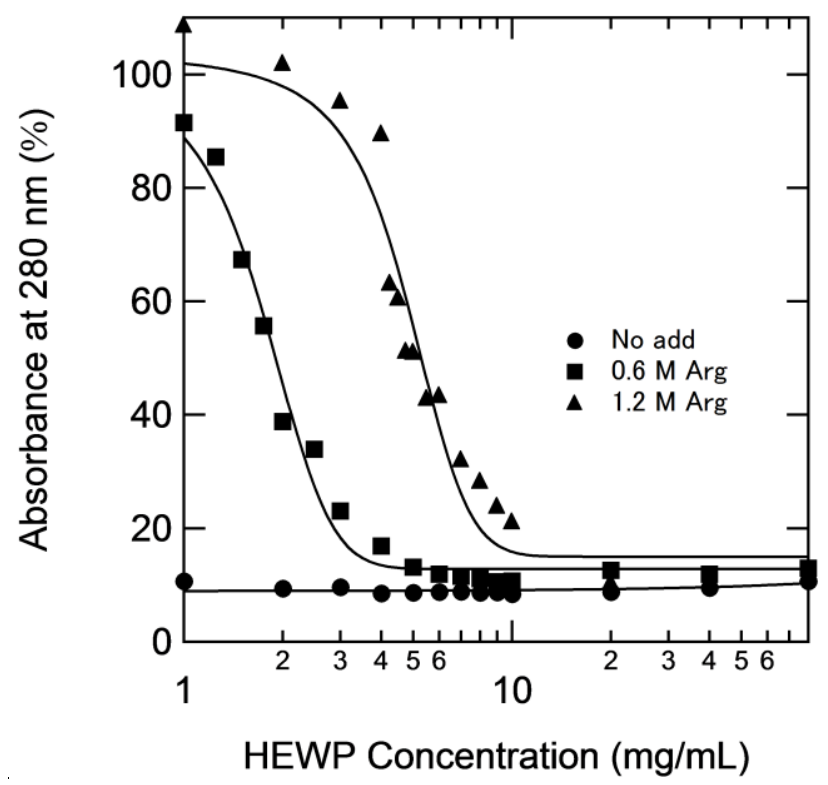

Fig. 3. Relative supernatant concentration of HEWP after heat treatment at $90^{\circ} \mathrm{C}$ for $30 \mathrm{~min}$. Samples contained $0 \mathrm{M}$ (circles, $\bullet$ ), 0.6 M (squares, $\mathbf{-}$ ), and 1.2 M (triangles, $\mathbf{\Delta}$ ) Arg with various concentrations of HEWP. The plot was fitted to a sigmoid equation (for squares and triangles) or linear equation (for circles). 


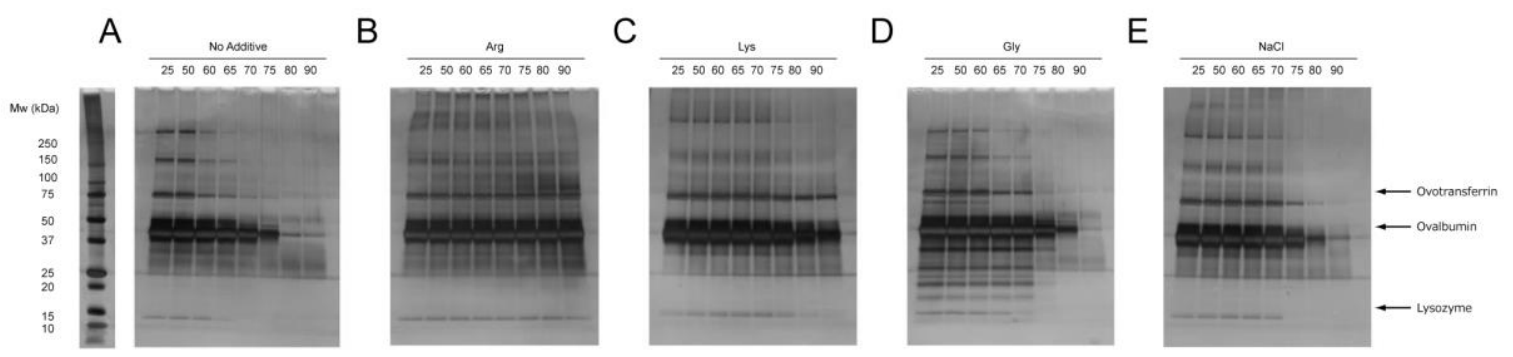

Fig. 4. SDS-PAGE analyses of $1 \mathrm{mg} \mathrm{mL}^{-1}$ HEWP after heat treatment at various temperatures in the absence (A) and presence of 0.6 M Arg (B), Lys (C), Gly (D), and $\mathrm{NaCl}$ (E). The numbers across the top show the temperature $\left({ }^{\circ} \mathrm{C}\right)$, and those on the left side show the molecular weight. 

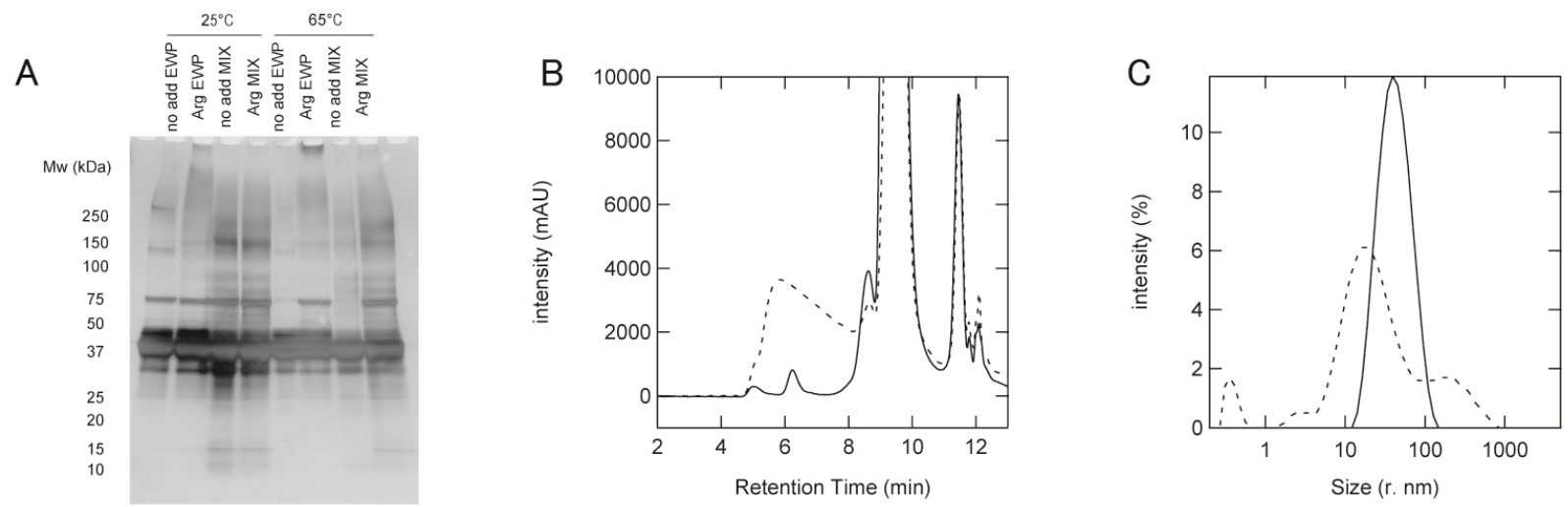

Fig. 5. (A) SDS-PAGE analyses of $1 \mathrm{mg} \mathrm{mL}^{-1} \mathrm{HEWP}$ and mixed proteins composed of LYZ, OVA, and OTA at a weight ratio of 2:32:7 after heat treatment at $65^{\circ} \mathrm{C}$ for 30 min without additives or with 0.6 M Arg. (B) SEC analysis of $1 \mathrm{mg} \mathrm{mL}^{-1} \mathrm{HEWP}$ with $0.6 \mathrm{M}$ Arg without heat treatment (solid line) or with heat treatment at $65^{\circ} \mathrm{C}$ for $30 \mathrm{~min}$ (dashed line). (C) DLS analysis of $1 \mathrm{mg} \mathrm{mL}^{-1} \mathrm{HEWP}$ with 0.6 M Arg (dashed line) or without additives (solid line) with heat treatment at $65^{\circ} \mathrm{C}$ for $30 \mathrm{~min}$. 

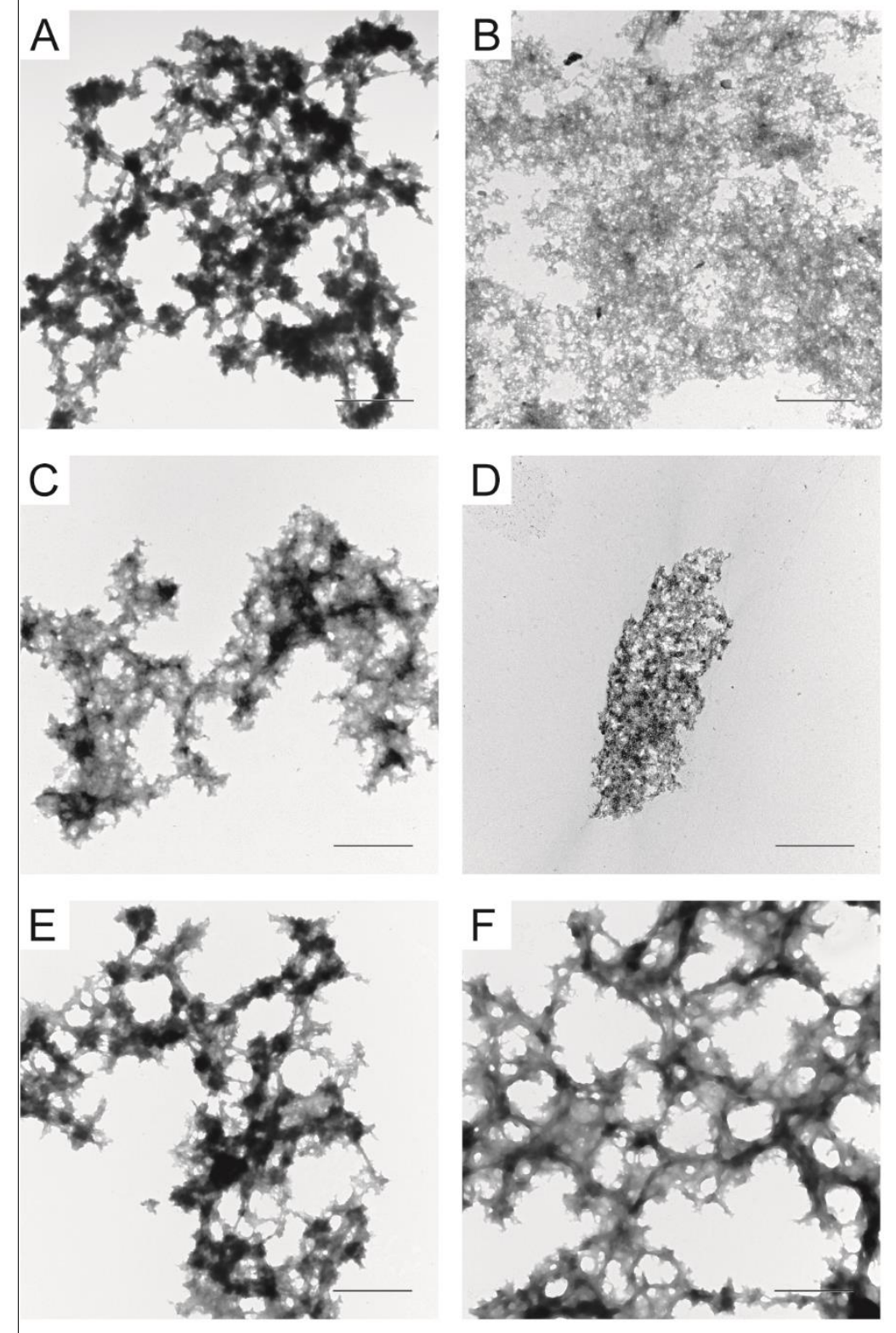

Fig. 6. Representative TEM images of HEWP aggregates in the absence (A) or presence of Arg (B), Lys (C), Gdn (D), Gly (E), and $\mathrm{NaCl}$ (F). All samples were analyzed by TEM after heat treatment at $90^{\circ} \mathrm{C}$ for $30 \mathrm{~min}$. The scale bars represent $1 \mu \mathrm{m}$. 


\section{Tables}

Table 1 Properties of the major proteins in HEWP.

\begin{tabular}{|c|c|c|c|c|c|c|c|c|c|}
\hline \multirow[t]{4}{*}{ Protein } & \multicolumn{4}{|c|}{ Properties of major proteins in HEWP } & \multicolumn{5}{|c|}{ Temperature of aggregation starting $\left({ }^{\circ} \mathrm{C}\right)^{\mathrm{d}}$} \\
\hline & \multirow{3}{*}{$\mathrm{w} \%{ }^{a}$} & \multirow{3}{*}{$\mathrm{p} I^{a, b, c}$} & \multirow{3}{*}{$\mathrm{M}_{\mathrm{w}}(\mathrm{kDa})^{a, b, c}$} & \multirow{3}{*}{$T_{\mathrm{m}}\left({ }^{\circ} \mathrm{C}\right)^{a}$} & \multirow[t]{2}{*}{ No } & \multirow{3}{*}{ Gly } & \multirow{3}{*}{$\mathrm{NaCl}$} & \multirow{3}{*}{ Lys } & \multirow{3}{*}{ Arg } \\
\hline & & & & & & & & & \\
\hline & & & & & additive & & & & \\
\hline Ovalbumin & 54 & $4.5(5.19)$ & $45(42.9)$ & 84 & 70 & 75 & 75 & 80 & 90 \\
\hline Ovotransferrin & 12 & $6.1(6.85)$ & $76(77.8)$ & 61 & 60 & 65 & 75 & 80 & ND \\
\hline Ovomucoid & 11 & $4.1[4.82]$ & $28[20.0]$ & 79 & ND & ND & ND & ND & ND \\
\hline Lysozyme & 3.4 & 10.7 & 14.3 & 75 & 65 & 70 & 75 & 80 & 90 \\
\hline
\end{tabular}

${ }^{a}$ Data are from (Rao, Rocca-Smith, \& Labuza, 2012).

${ }^{\mathrm{b}}$ Data shown in parentheses are from (Qiu et al., 2012).

${ }^{\mathrm{c}}$ Data shown in square brackets are from (Guérin-Dubiard et al., 2006).

$\mathrm{w} \%, \mathrm{p} I, \mathrm{M}_{\mathrm{w}}$, and $T_{\mathrm{m}}$ indicate relative weight of major proteins of HEWP, isoelectric point, molecular weight, and denaturation temperature, respectively. ND, no aggregates even after heat treatment at $90^{\circ} \mathrm{C}$ for $30 \mathrm{~min}$.

${ }^{\mathrm{d}}$ The temperature at which aggregation began (defined as the temperature at which the color of the band diminished) for $1 \mathrm{mg} \mathrm{mL}^{-1} \mathrm{HEWP}$ was analyzed by SDS-PAGE (Fig. 4) in the presence or absence of $0.6 \mathrm{M}$ additives (Arg, Lys, Gly, and $\mathrm{NaCl}$ ). 


\section{Highlights}

- $\quad 0.6 \mathrm{M}$ Arg suppressed the thermal aggregation of $1 \mathrm{mg} \mathrm{mL}^{-1} \mathrm{HEWP}$ heated at $90^{\circ} \mathrm{C}$.

- Lys, $\mathrm{Gdn}, \mathrm{NaCl}$, and Gly did not suppress the thermal aggregation of HEWP.

- The reason why Arg suppresses the aggregation of protein mixture is proposed.

- Arg is a reasonable additive for safe sterilization of HEWP. 